\title{
Degloving injuries of trunk and limbs: comparison of outcomes of early versus delayed assessment by the plastic surgery team
}

\author{
Desenluvamentos de tronco e membros: comparação dos resultados da \\ avaliação precoce ou tardia pela cirurgia plástica
}

Daniel Francisco Mello1; José Cesar Assef, tCBC-SP2; Sillvia Cristine Soldá, TCBC-SP²; Américo Helene Jr1

A B S T R A C T

\begin{abstract}
Objective: to analyze cases of degloving of the trunk and limbs, comparing outcomes of early versus delayed assessment by the plastic surgery team. Methods: we conducted a retrospective analysis of medical charts. Patients comprised two groups: Group I - early assessment, performed within 12 hours post trauma; and Group II - delayed assessment, performed more than 12 hours post trauma. We defined primary grafting as the use of skin from the traumatized skin flap. We excluded cases involving hands, feet or genitalia. Results: there were 47 patients treated with degloving injuries between 2002 and 2010. The mean body surface area affected was $8.2 \%$. Lower limbs were the most frequently affected site (95.7\%), whether alone or in association with lesions to other sites. Delayed assessment by the plastic surgery team occurred in 25 cases. Mean hospital stay was 36.1 days for Group I and 57.1 days for Group II ( $p=0.026)$. Regarding the number of surgical operations (skin grafts), Group I received a mean of 1.3, while Group II underwent $1.6(p=0.034)$. Conclusion: based on length of hospital stay and number of operations in trauma patients with degloving of the trunk and limbs, plastic surgery assessment should be carried out early.
\end{abstract}

Key words: Skin Transplantation. Soft Tissue Injuries. Wound Closure Techniques. Dermatologic Surgical Procedures. Fascia/ Surgery

\section{INTRODUCTION}

$\mathrm{D}$ eglovings result from the application of high intensity forces with tangential vectors that determine compression, stretch, twist and tissue friction, causing avulsion of skin and subcutaneous tissue from the fascia and muscle planes, with damage to the musculocutaneous and fasciocutaneous perforating vessels ${ }^{1-4}$.

The first reports date back to the early twentieth century, in upper limb injuries caused by occupational accidents with drying machines in laundries, known in the literature as wringer arm (MacCollum, 1939). With the advent of the automobile industry, the most frequent mechanism became trampling ${ }^{1-3,5}$.

The bearer of this type of injury is usually a multiple trauma patient, with high incidence of associated injuries, particularly fractures and vascular lesions $s^{5-7}$. The early and simultaneous participation of the plastic surgeon is essential in order to assess tissue viability and guide treatment ${ }^{8}$. The use of traumatized skin as partial or total thickness primary grafting, initially described by Farmer in 1939, is considered the ideal conduct ${ }^{1-3,8,9}$.
This work aims to analyze patients suffering from degloving of trunk and limbs, comparing the results of early or late evaluation by the Plastic Surgery team.

\section{METHODS}

We performed a retrospective analysis of medical records of patients suffering from degloving affecting the trunk and limbs treated between January 2002 and January 2010 at the Emergency units and evaluated by the Plastic Surgery team, Department of Surgery, Faculdade de Ciências Médicas, Santa Casa de Misericórdia de São Paulo. Cases involving hands, feet or genitals were excluded. This study was approved by the Comitê de Ética e Pesquisa (CEP) of the Irmandade da Santa Casa de São Paulo (in 161/10).

The evaluation by the Plastic Surgery team was requested after the initial care held by General Surgery, Pediatric Surgery and Orthopedics teams. It was considered an early assessment performed within 12 hours (Group I 22 patients) and late, the ones performed after 12 hours of admission (Group II - 25 patients). To evaluate the

1. Serviço de Cirurgia Plástica, Departamento de Cirurgia, Faculdade de Ciências Médicas da Santa Casa de Misericórdia de São Paulo - SP Brazil; 2. Serviço de Emergência, Departamento de Cirurgia, Faculdade de Ciências Médicas da Santa Casa de Misericórdia de São Paulo - SP Brazil. 
percentage of degloved body surface (DBS) we used Lund and Browder table ${ }^{10}$.

We evaluated data regarding: gender, age, mechanism of injury, DBS, associated injuries (head, spinal cord, thoracic, abdominal and pelvic-perineal traumas), fractures, vascular injury, treatments performed, number of skin grafts, number of necessary interventions, graft integration rate, length of stay, complications and mortality.

We defined primary graft the one performed in the first 12 hours after admission, with the use of skin from the degloved area, in full or partial thickness, and late, the graft carried out after this period, with skin from nontraumatized donor sites.

\section{RESULTS}

The study series comprised 47 patients, 22 (47\%) evaluated early on and 25 (53\%) late. Thirty-three (70\%) patients were male and $14(30 \%)$ female, with a mean age of 30.6 years $(2-72$, SD 18.8). There was no statistically significant difference in the comparison between gender $(p=0.775)$ and age $(p=0.091)$. The most common trauma mechanism was trampling, followed by motorcycle accidents in both groups (Figure 1a). There was also no statistically significant difference when comparing the trauma mechanisms $(p=0.542)$. The average degloved body surface (DBS) was $8.2 \%$ (3-22\%, $S D=4.5)$. There was no statistically significant difference when comparing the average DBS (Figure $1 \mathrm{~b}$ ) between groups $(p=0.5)$. There were associated lesions (brain injury, spinal cord, thoracic, abdominal, pelvic-perineal) in 20 patients (42.5\%); $33(70 \%)$ presented associated fractures (Table 1). We observed a statistically significant difference when comparing the occurrence of fractures in Groups I and II, with no statistically significant difference as for the presence of vascular injuries and other associated injuries.

The mean hospital stay was 47.3 days (7-239, $S D=40)$. When comparing the length of stay and number of skin grafts, there were statistically significant differences (Table 2). Patients evaluated early underwent 14 primary graftings, two late graftings (15th and 17th day of hospitalization), two primary syntheses, two primary amputations with primary grafting and two primary amputations. The posteriorly evaluated ones underwent 18 late graftings (after the 14th up until the 30th day), three primary syntheses, three amputations and one debridement.

In the 16 patients undergoing primary grafting (Group I), DBS varied from four to $16 \%$, there being

Table 1 - Comparative data on fractures, vascular injuries and associated injuries.

\begin{tabular}{|c|c|c|c|c|c|c|c|c|c|}
\hline \multirow[t]{2}{*}{ Group } & \multicolumn{2}{|c|}{ Fractures } & \multicolumn{3}{|c|}{ Vascular injuries } & \multicolumn{4}{|c|}{ Associated injuries } \\
\hline & Yes & No & & Yes & No & & es & & No \\
\hline GI & $12(54.5 \%)$ & $10(45.5 \%)$ & 8 & $(36.4 \%)$ & $14(63.6 \%)$ & & $36.4 \%)$ & 14 & $63.6 \%)$ \\
\hline GII & $21 \quad(84 \%)$ & $4 \quad(16 \%)$ & 5 & $(20 \%)$ & $20 \quad(80 \%)$ & 12 & $(48 \%)$ & 13 & $(52 \%)$ \\
\hline$G \mid \times G \|(p)$ & \multicolumn{2}{|c|}{0.028} & \multicolumn{3}{|c|}{0.211} & \multicolumn{4}{|c|}{0.421} \\
\hline
\end{tabular}

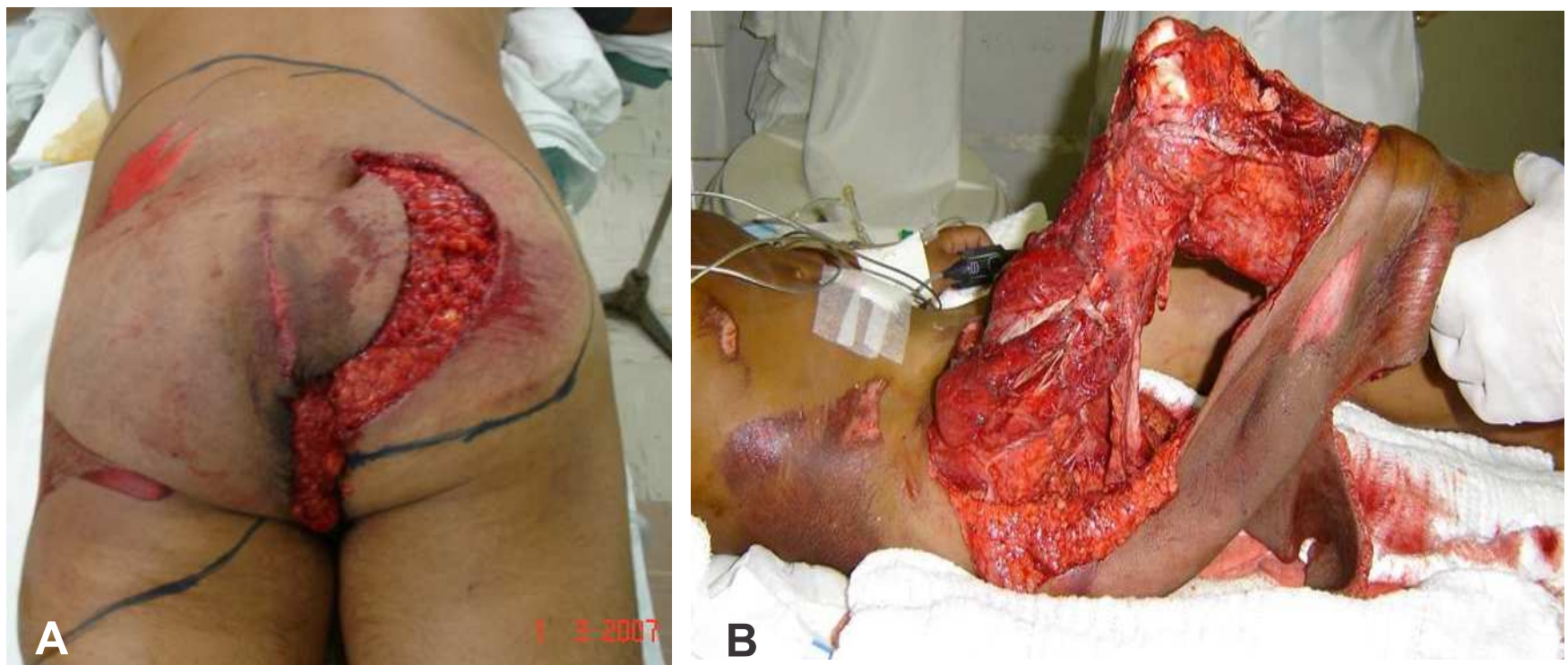

Figure $1 a$ - Victim of motorcycle accident followed by trampling. Degloving Area Extension after demarcation. Figure 1b - Circumferential open degloving in lower limb - initial evaluation in the emergency room. 
integration of more than 95\% in ten cases (Figures 2a and $2 b$ ), without the need for further skin-covering procedures. In the six other cases, there was integration of about $50 \%$ in three cases and subtotals losses in the other patients (who developed hemodynamic instability and need for abdominal and thoracic reoperations). In two cases we used skin from the areas of amputated limbs not affected by degloving.

In cases where primary grafting was not possible, it was necessary to wait a period of 14 to 30 days to begin the cover (late grafting). During this period we performed debridement and serial dressing exchanges until the healing wound presented an appropriate bed (granulation tissue). We used non-traumatized skin from donor sites mainly in the lower limbs and trunk. The evolution of these patients after grafting was satisfactory as for graft integration (above 95\%).

We observed complications in 29 (62\%) patients (Table 3 ). In 12 patients there was the development of infection in the degloved area, of which seven were evaluated late and five early. Among patients undergoing primary synthesis (5 cases), three developed infection (Figures $3 a$ and $3 b$ ), which did not occur in any patient undergoing primary grafting. Two patients $(4.2 \%)$ died after 15 and 25 days of hospitalization.

\section{DISCUSSION}

Deglovings occur more frequently in males, since they are a condition consequent to trauma. The extent and the severity of injuries vary widely, making comparative analysis difficult. There may be extensive deglovings in patients without associated fractures or vascular injuries, as well as small extension injuries, injuries associated with fractures, vascular injuries and / or other associated injuries $^{11-13}$

Fractures are present in $40-85 \%$ of cases in the degloving-affected areas, and the reduction and fixation should take place before the soft tissue approach, which may explain, though not delay, the Plastic Surgery assessment $2,7,8$

Associated injuries - head, spinal, abdominal, pelvic-perineal and chest traumas - are present in most patients, and there may be the need for operations to control

Table 2 - Comparative data related to length of stay and number of skin grafts between groups.

\begin{tabular}{lccccc}
\hline Group & \multicolumn{2}{c}{ Length of stay } & \multicolumn{2}{c}{ Number of grafting skin } \\
\cline { 2 - 6 } & Mean & SD & Mean & SD \\
\hline GI & 36.1 & 29.2 & 1.3 & 1.1 \\
Gll & 57.1 & & 45.9 & 1.6 & 0.034 \\
Gl x GII $(p)$ & & 0.026 & & & 1.3 \\
\hline
\end{tabular}
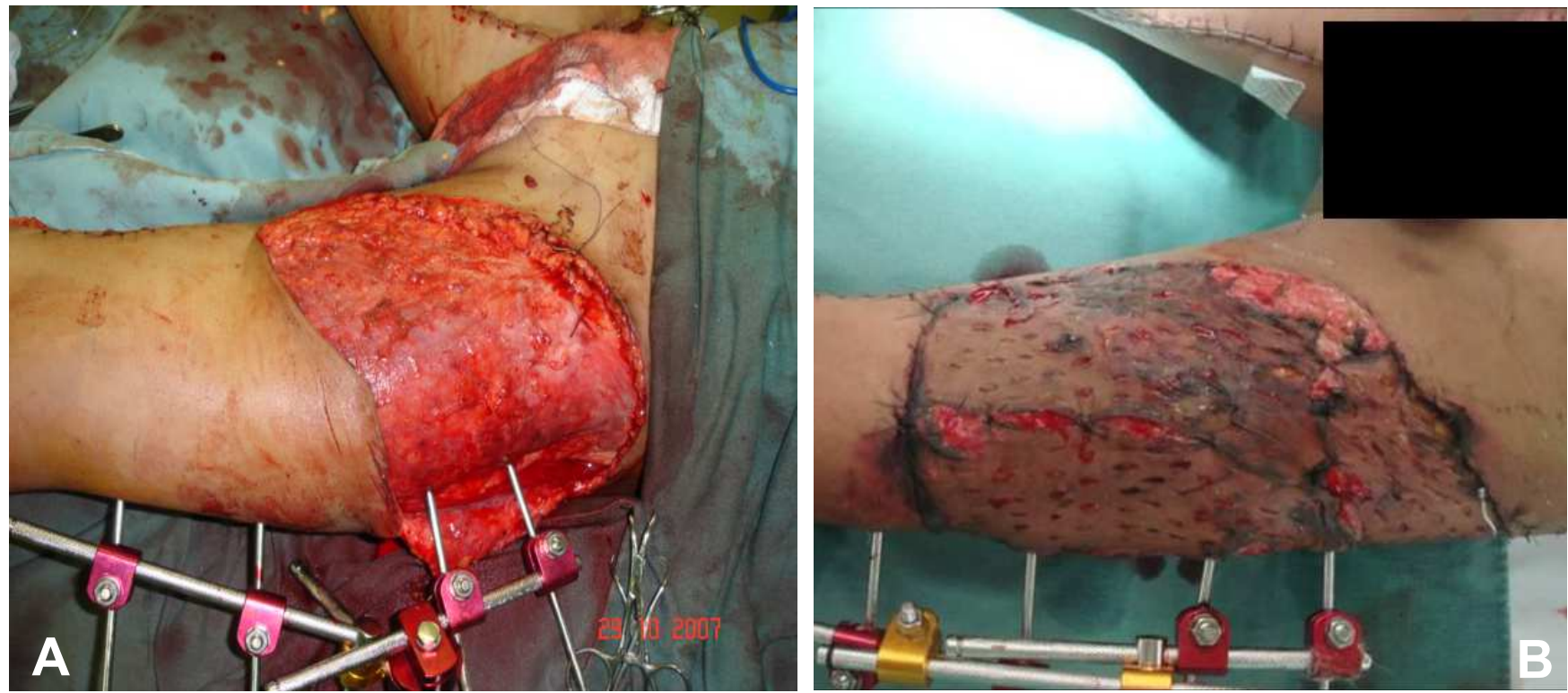

Figure 2a - Degloving in left lower limb. Intraoperative evaluation after external fixation for femur fracture. Figure $2 b$ - Degloving in left lower limb. After treatment - primary grafting, partial thickness skin - fifth postoperative day - full integration. 

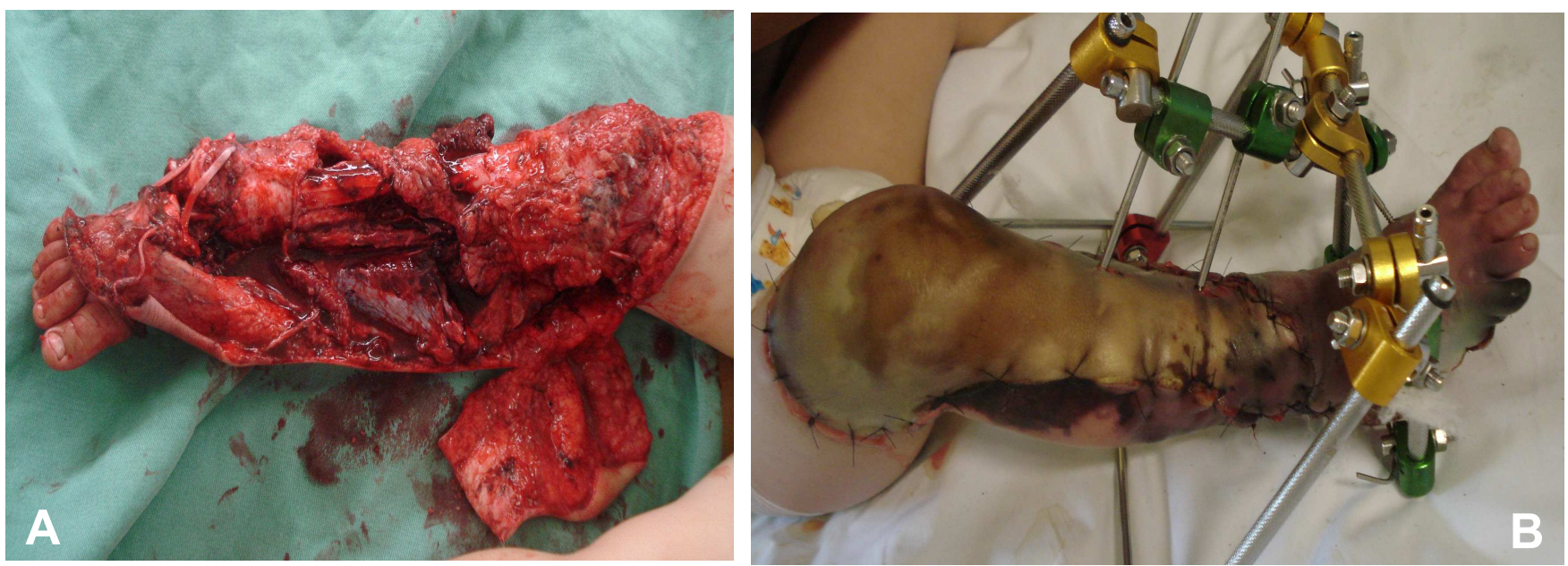

Figure 3a - Circumferential degloving of lower limb. Figure 3b-Circumferential degloving of lower limb - underwent primary synthesis. Fifth postoperative day - cutaneous ischemia and infection.

Table 3 - Number of complications (29 patients).

\begin{tabular}{lcc}
\hline Complications & GI $(n=13)$ & GII $(n=16)$ \\
\hline Infection / necrosis of skin, soft tissue and amputation stump & 7 & 12 \\
Urinary infection & 4 & 6 \\
Problems related to synthesis and fixing materials & 4 & 5 \\
Pulmonary complications & 2 & 5 \\
Transfusion reaction / coagulopathy & 4 & 7 \\
Vascular complications & 2 & 3 \\
Pressure ulcer & 1 & 1 \\
Kidney failure & 1 & 1 \\
Other & 2 & 2 \\
\hline
\end{tabular}

life-threatening injuries. In such critical situations, simultaneous and rapid participation of the plastic surgeon may be beneficial to the removal and preparation of the traumatic flap for later use, the skin being stores in a tissue bank $^{3,11,13}$.

We observed no statistical differences between groups regarding the following variables: gender, age, percentage of degloved body surface (\% DBS), mechanism of trauma, presence of vascular injury and associated injuries. Thus, we could consider the groups comparable. On the other hand, there was statistical difference when analyzed the incidence of fractures, which was significantly higher in Group II. This may reflect the greater attention given to the fractured patient by the team performing the initial assessment and justify any delay of evaluation request for the Plastic Surgery team.

According Kudsk et al., the principles of local treatment consists in evaluating the viability of the flaps, debridement of necrotic or mutilated tissues, use of nonviable flap areas as donor of skin grafts in partial or total thickness, fixation and immobilization of both grafts and fractures ${ }^{2}$.
Controversy exists regarding the best option as to grafts taken from the traumatic flap, whether in partial or full thickness. Ideally, all available skin should be used, even when there is evidence of friction burns ${ }^{1-3,5,9-12}$. If there are no conditions for integration, this skin will work temporarily as a biological dressing.

Total skin grafts usually have better functional and aesthetic results due to lower secondary contracture. Grafting in partial thickness may be indicated for more critical situations, considering the greatest chance of integration, with lower aesthetic results, especially when subjected to prior expansion ${ }^{14-17}$, although there seems to be significant difference in the rates of integration between the different graft thicknesses.

Primary synthesis should be avoided in areas with extensive deglovings, as noted by numerous authors ${ }^{1-3,5,17}$. We used it in five patients, with $80 \%$ complication rate (total necrosis of the repositioned traumatic flap), as well as local infection in three cases.

Hospital stay was prolonged in both groups (36 days in Group I and 57 in Group II), although significantly higher in Group II. Kudsk et al. reported an average hospi- 
tal stay of 68 days². Milcheski et al. described a mean hospital stay of 46.2 days for patients undergoing primary suture and 32.5 days for patients undergoing primary grafting $(p<0.001)^{18}$.

The variations in number, severity and heterogeneity of associated injuries, which occurred in $42.5 \%$ of patients, should be considered, since they may have impact on mortality and on the need for additional tests and procedures during the initial assessment. The presence of fractures and / or vascular lesions, even if isolated, could delay the perceived need for evaluation request by the plastic surgeon $17,19,20$.

We observed that the determinant of hospital stay was the presence of extensive degloving area, especially in patients who did not receive the appropriate initial treatment. There was the need to wait for a delimitation of ischemic tissues and the subsequent healing (granulation) of the bed before grafting. Importantly, in these situations there is need of skin taken from non-traumatized donor areas, which may require multiple procedures $8,18,21$.

Early coverage of the bloody areas decreases protein and electrolyte losses, as well as the basal energy expenditure, the need for dressing changes, the costs, the anesthetic risk, length of stay and functional sequelae $e^{22,23}$.

Importantly, during the initial evaluation of the polytrauma patient, the plastic surgeon must be present to contribute to a better result in an attempt to decrease complications and mortality, as well as the length of stay and number of operations, as demonstrated in this study. For this, the awareness of multidisciplinary teams is fundamental $18,24,25$.

The analysis of the data from this study shows that early assessment and the possibility of primary grafting have a positive impact on the evolution of patients victims of degloving, resulting in a shorter hospital stay and less operations.

\title{
R E S U M O
}

\begin{abstract}
Objetivo: analisar os casos de desenluvamentos de tronco e membros, comparando os resultados da avaliação precoce ou tardia pela equipe de cirurgia plástica. Métodos: análise retrospectiva de prontuários. Os pacientes foram separados em dois grupos: Avaliação precoce - Grupo I (realizada no intervalo de até 12 horas após o trauma) e Avaliação tardia - Grupo II (realizada mais de 12 horas após o trauma). Definiu-se como enxertia primária aquela realizada com pele proveniente do retalho traumático. Foram excluídos os casos com acometimento de mãos, pés ou genitália. Resultados: foram atendidos 47 pacientes. A superfície corporal lesada média foi 8,2\%. Os membros inferiores foram os locais mais acometidos, em 95,7\%, isoladamente ou em associação com lesões em outros locais. A avaliação da Cirurgia Plástica foi solicitada tardiamente em 25 casos. Observou-se tempo médio de internação de 36,1 dias para o grupo I e de 57,1 para o grupo II $(p=0,026)$. Em relação ao número de cirurgias (enxertias de pele), observou-se média de 1,3 no grupo / e 1,6 no grupo II ( $p=0,034)$. Conclusão: em doentes politraumatizados, vítimas de desenluvamento de tronco e membros, podemos concluir, no que se refere ao tempo de internação e número de operações, que a avaliação da Cirurgia Plástica deve ser precoce.
\end{abstract}

Descritores: Transplante de pele. Lesões dos Tecidos Moles. Técnicas de Fechamento de Ferimentos. Procedimentos Cirúrgicos Dermatológicos. Fáscia/cirurgia.

\section{REFERENCES}

1. Mandel MA. The management of lower extremity degloving injuries. Ann Plast Surg. 1981;6(1):1-5.

2. Kudsk KA, Sheldon GF, Walton RL. Degloving injuries of the extremities and torso. J Trauma. 1981;21(10):835-9.

3. Hidalgo DA. Lower extremity avulsion injuries. Clin Plast Surg. 1986;13(4):701-10.

4. Askins G, Finley R, Parenti J, Bush D, Brotman S. High-energy roller injuries to the upper extremity. J Trauma. 1986;26(12):1127-31.

5. Slack CC. Friction injuries following road accidents. Br Med J. 1952;2(4778):262-4

6. Tseng S, Tornetta P 3rd. Percutaneous management of MorelLavallee lesions. J Bone Joint Surg Am. 2006;88(1):92-6.

7. Phillips TJ, Jeffcote B, Collopy D. Bilateral Morel-Lavallée lesions after complex pelvic trauma: a case report. J Trauma. 2008;65:70811

8. Mello DF, Demario LA, Soldá SC, Helene Jr A. Desenluvamentos fechados: lesão de Morel-Lavallée. Rev Bras Cir Plást. 2010:25(2):355-60.

9. Farmer AW. Treatment of avulsed skin flaps. Ann Surg 1939;110(5):951-9.
10. McManus WF, Pruit BA. Thermal injuries. In: Mattox RH, Moore EE, Feliciano DV, editors. Trauma. 2nd ed. Norwalk: Appleton and Lange; 1991. p. 751-64

11. MacKenzie EJ, Bosse MJ, Kellam JF, Burgess AR, Webb LX Swiontkowski MF, et al. Factors influencing the decision to amputate or reconstruct after high-energy lower extremity trauma. J Trauma. 2002;52(4):641-9. Erratum in: J Trauma. 2002;53(1):48.

12. Southern SJ, Hart NB, Venkatramakishnan V, Nieuwoudt F, Villafane $O$. Lower limb salvage using parts of the contralateral amputated leg. Injury. 1997;28(7):477-9.

13. Steiner CL, Trentz O, Labler L. Management of Morel-Lavallee lesion associated with pelvic and/or acetabular fractures. Eur J Trauma Emerg Surg. 2008; 34(6):554-60.

14. Meara JG, Guo L, Smith JD, Pribaz JJ, Breuing KH, Orgill DP. Vacuum-assisted closure in the treatment of degloving injuries. Ann Plast Surg. 1999;42(6):589-94.

15. Josty IC, Ramaswamy R, Laing JH. Vacuum assisted closure: an alternative strategy in the management of degloving injuries of the foot. Br J Plast Surg. 2001;54(4):363-5.

16. Khan U, Ho K, Deva A. Exchanging split-skin grafts to reduce donor morbidity in limited pretibial degloving injuries. Plast Reconstr Surg. 2004;113(5):1523-5. 
17. Arnez ZM, Khan U, Tyler MP. Classification of soft-tissue degloving in limb trauma. J Plast Reconstr Aesthet Surg. 2010;63(11):18659.

18. Milcheski DA, Ferreira MC, Nakamoto HA, Tuma Jr P, Gemperli R. Tratamento cirúrgico dos ferimentos descolantes nos membros inferiores: proposta de protocolo de atendimento. Rev Col Bras Cir. 2010;37(3):199-203.

19. Jeng SF, Wei FC. Technical refinement in the management of circumferentially avulsed skin of the leg. Plast Reconstr Surg. 1997; 100(6):1434-41.

20. Ergün SS, Erözgen F, Akdemir OC, Ziyade S, Íçten S, Egeli U Missed closed degloving injury of the sacro-gluteal region. Eur J Plast Surg. 2010;33(1):41-44.

21. Hopgood B, Bessey PQ, Thorpe J, Blanton J, Yurt RW. Burn Center Management of Degloving Injuries: 177. In: Proceedings of the 38th Annual Meeting. April 4-7, 2006; Las Vegas, Nevada; 2006. 27(2) Suppl:S138 (J Burn Care Res. 2006;27(2):S138).

22. Sarlak $A Y$, Buluç $L$, Alc $T$, Alponat $A$. Degloving injury of pelvis treated by internal fixation and omental flap reconstruction. J Trauma. 2006;61(3):749-51.
23. Schneider AM, Morykwas MJ, Argenta LC. A new and reliable method of securing skin grafts to the difficult recipient bed. Plast Reconstr Surg. 1998;102(4):1195-8.

24. Mellado JM, Pérez del Palomar L, Díaz L, Ramos A, Saurí A. Longstanding Morel- Lavallée lesions of the trochanteric region and proximal thigh: MRI features in five patients. AJR Am J Roentgenol. 2004;182(5):1289-94

25. Morris M, Schreiber MA, Ham B. Novel management of closed degloving injuries. J Trauma. 2009;67(4):E121-3.

Received on 10/06/2014

Accepted for publication 20/08/2014

Conflict of interest: none.

Source of funding: none.

Address for correspondence:

Daniel Francisco Mello

E-mail: mello.plastica@gmail.com 